\title{
KNITTING HOPE OF LEADERSHIP IN CREATING CARING BEHAVIOR IN THE INDUSTRIAL 4.0 REVOLUTION
}

\author{
Widiantara Putu Agus ${ }^{\star}$, Suardana Ida Bagus Raka \\ Undiknas Graduate School, Bali, Indonesia \\ *E-mail: aw8019@gmail.com
}

\begin{abstract}
This research is motivated by nurses who have no personal care on their patience because they keep focusing on medical performance. The purpose of this study is to determine the influence of leadership variables, organizational culture, and work environment on job satisfaction, to find out the influence of leadership variables, organizational culture, work environment on nurses caring behavior and to determine the effect of job satisfaction variables on nurses caring behavior. Data are collected using questionnaires and interviews with a sample of 115 respondents. This research technique uses the Amos for Windows 23.0 to analyze the data. The analysis begins with the process of evaluating SEM assumptions through evaluation of data normality, Confirmatory factor analysis (CFA) and influence analysis with SEM. The results of this study indicate that there is a significant positive influence between leadership on job satisfaction, a positive and significant influence between organizational culture on job satisfaction, positive and significant influence between work environment on job satisfaction, There is a positive and significant effect between leadership on nurses' caring behavior, positive and significant effect between organizational culture on nurses' caring behavior, no effect between work environment on nurses caring behavior, and positive and significant effect between job satisfaction on nurses caring behavior.
\end{abstract}

\section{KEY WORDS}

Leadership, organizational culture, work environment, job satisfaction, nurse caring behavior.

The hospital is a means of health efforts that organizes health service activities provides services. Complex services are professionally managed by human resources. One of the service providers in the hospital is a nurse. Hospital nurses may practice nursing in the form of nursing services known as nursing care. Nurses provide nursing services at the hospital 24 hours a day and have constant contact with patients (Nursalam, 2009).

Health services in hospitals are provided by the health team including the nursing team. This team is part of a bigger team, the forefront team who deals with patients for 24 hours; therefore it is necessary to have high quality nursing resources that can respond to existing conditions. Services in hospitals are more heavily borne by nursing, so the role of nurses is very large in determining the quality of service (Huber, 2006).

The basic cause of nurses' caring behavior is because nurses focus more on medical performance. This condition is strengthened by the factors of leadership, management support, and work environment that does not support nurses towards nurses caring behavior (Tomey, 2006).

The formation of caring behavior is strongly influenced by the shared value system adopted by nurses which is reflected in the vision, mission, and goals of the hospital. The vision, mission, and objectives to be achieved reflect the culture of an organization. A strong organizational culture can create common goals, employee motivation and control structures in shaping behavior to improve organizational performance that has an impact on the performance of organizational members Kreitner \& Kinicki (2010).

The formation of caring behavior is strongly influenced by the shared value system adopted by nurses which is reflected in the vision, mission, and goals of the hospital. The vision, mission, and objectives to be achieved reflect the culture of an organization. A strong organizational culture can create common goals, employee motivation, and control structures 
in shaping behavior to improve organizational performance that has an impact on the performance of organizational members, as said by Kreitner \& Kinicki (2010).

Work environment issues in an organization are very important, in this case it is necessary to regulate and organize work environment factors in organizing organizational activities. The company must endeavor so that the factors included in the physical work environment can be endeavored in such a way and have a positive influence on increasing employee job satisfaction.

The phenomenon that occurs at UPTD Bali Mandara Hospital is related to nurses caring behavior, stating that the high workload experienced by nurses results in complaints for patients. Common complaints for nurses are stating that they are not friendly, impatient, lacking attention, sensitivity, speed, and accuracy of responding to patients' problems.

Another phenomenon related to caring behavior in terms of individual and organizational factors is shown from nurses' complaints in the form of an unbalanced ratio of nurses to clients, unequal distribution of nurses in each room so that it can affect nurses caring behavior. Client complaints are obtained from suggestion boxes such as nurses to be more agile in fulfilling client calls, friendlier, and more polite in dealing with clients. While the interview results obtained by nurses shows that their work are limited to routine, unclear career paths and lack of attention from the leadership.

\section{LITERATURE REVIEW}

Caring is considered a basic concept of the role of nursing as a framework and guide to nursing practice; this involves the totality of individuals to provide optimal level of care to patients. (Kathyrine A, 2018). Several theories in nursing have been developed from various perspectives to explain and describe caring. Caring is a care that is given continuously focused on physical and mental care and increase patient safety (Watson, 2005).

According to Wolf, Colohan, Warwick, Ambrose \& Giardino (2004) have developed a list of nurses caring behavior inventory, Wolf wrote in a row of ten behavioral ratings that show caring nurses. The ten behaviors include: a. Listen attentively, b. Give a sense of comfort, c. Telling the truth, d. Have patience, c. Responsible, d. Provide information so patients can make decisions, e. Give touch, h. Showing sensitivity, i. Showing respect for patients, j. Call the patient by his name.

Leadership is the ability to take decisions that are practical, realistic, and can be implemented as well as facilitate the achievement of organizational goals (Agustina, 2013). Katz and Kahn in Cepi Priatna (2015) argue that leadership is an increase in influence little by little above mechanical compliance with routine organizational directions. In addition, according to Khajeh (2018), Leadership is one of the main determinants related to the success and failure of an organization. Leadership style is the way people are directed and motivated by a leader to achieve organizational goals. There are six main leadership styles namely transformation, transactional, autocratic, charismatic, bureaucratic and democratic.

According to the results of Amin Nikpour's study(2017), organizational culture not only has a direct impact on organizational performance, but also indirectly affects organizational performance. Schein (Mangku state, 2005) states that organizational culture is a set of assumptions or systems of beliefs, values, and norms developed in organizations that serve as guidelines for behavior by members to overcome the problems of internal adaptation and external adaptation. In addition, organizational culture is also used as a guideline in the behavior of members to overcome the problems of external adaptation and internal integration.

Robbins \& Judge (2010) suggested that "Organizational culture is a set of values, principles, traditions and ways of working shared by and influencing the behavior and actions of members of the organization". In most organizations, these shared values and practices have developed rapidly along with the times and really really influence how an organization is run.

According to Irham Fahmi in Bijaya (2006), organizational culture is a habit that has lasted a long time and is used and applied in the life of work activities as one of the drivers to 
improve the quality of work of employees and company managers. it was concluded that the organizational culture in this study was the organizational value system adopted by members of the organization, which then influenced the work and behavior of the members of the organization. According to Turner in Wibowo (2010) organizational culture are behavioral, social and moral norms that underlie every action in an organization and are shaped by the beliefs, attitudes and priorities of its members.

According to Sedarmayanti (2014) the physical work environment is all physical forms that exist around the workplace that can affect employees both directly and indirectly. According Sedarmayanti (2014) argues that the physical work environment is the whole or every aspect of physical and socio-cultural phenomena that surround or influence the individual. Based on the opinion of experts, it can be concluded that, the physical work environment is everything that is around the workplace of employees more focused on objects and situations around the workplace so that it can affect employees in carrying out their duties. The physical work environment is an environment that focuses on everything that is around the workplace that directly affects employees.

Harahap, (2010) explains performance as a record of the results of work obtained by certain employees through activities within a certain period. Performance objectives according to Harahap (2010) are: (1) The proficiency of the ability of a new task is intended to improve the results of performance and activities. (2) Proficiency of new knowledge which will help employees with solving complex problems of the activity of making decisions on assignments. (3) Proficiency or improvement in attitudes towards coworkers with a performance activity. (4) Performance improvement activity targets. (5) Improvements in quality or production. (6) Repair in time or delivery.

Job satisfaction is felt by employees because there are things that underlie it. Basically, someone will feel comfortable and the level of loyalty at his job will be high if in work the person gets job satisfaction in accordance with what is desired. Job satisfaction reflects workers' feelings towards their work (Nasution, Erni H, 2018). According Siagian (2009) argues that job satisfaction is a perspective of someone, both positive and negative about their work. Many factors need to be paid attention to in analyzing someone's job satisfaction, if someone has autonomy or acted in his or her work, there are variations, make important contributions to the success of the organization and employees get feedback about the results of their work, they will be satisfied.

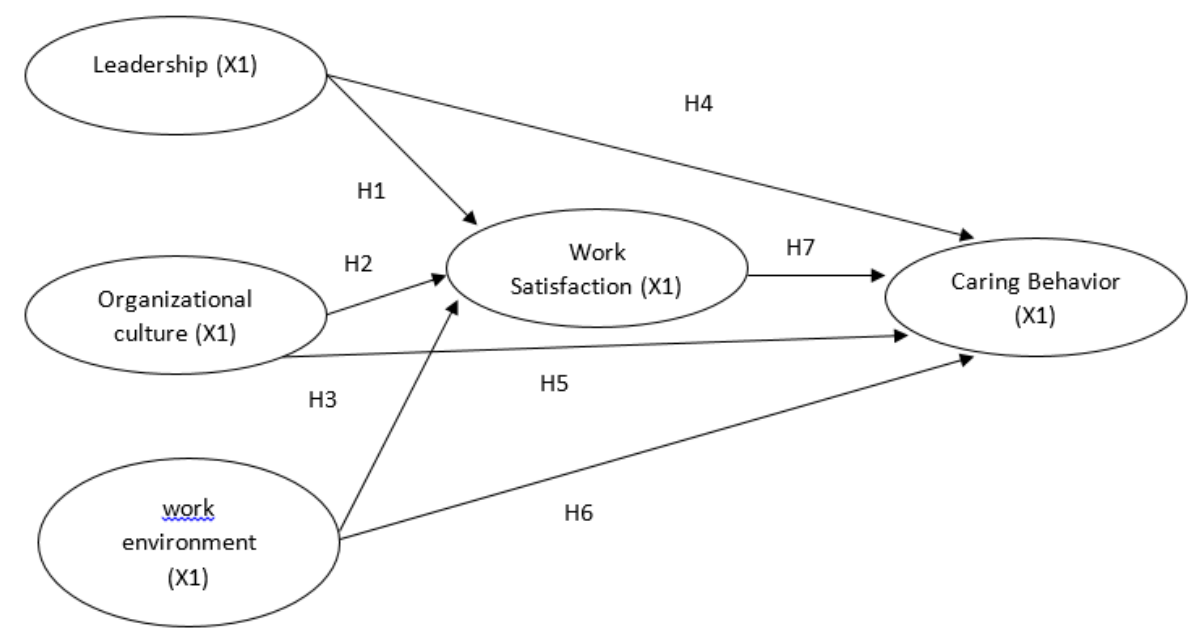

Figure 1 - Research Framework (Source: Research processed, 2019)

Hypotheses. This research is a scientific approach so several hypotheses can be drawn. According to (Sugiyono: 2016) "Hypothesis is a temporary answer to the formulation of research problems". Based on the things that have been stated above, the researcher can draw several hypotheses as a temporary answer to the problems that have been formulated and which will be tested and proven true, namely: 
$\mathrm{H} 1$ : There is an Effect of Leadership on Job Satisfaction;

$\mathrm{H} 2$ : There is an Effect of Organizational Culture on Job Satisfaction;

H3: There is an Effect of the Work Environment on Job Satisfaction;

$\mathrm{H} 4$ : There is an Effect of Leadership on Caring Behavior;

H5: There Is an effect of Organizational Culture on Caring Behavior;

$\mathrm{H6}$ : There is an Environmental Effect on Caring Behavior;

$\mathrm{H7}$ : There is an effect of Job Satisfaction on Caring Behavior.

\section{METHODS OF RESEARCH}

This research was conducted at UPTD Bali Mandara Hospital. The reason for choosing this research location is because there has been no previous research that examined about caring behavior in UPTD Bali Mandara Hospital. Through this study, researchers are hoping to be able to contribute ideas to improve nurses caring behavior in UPTD. Bali Mandara Hospital. Population is a generalization area consisting of objects or subjects that have certain quantities and characteristics determined by research to be studied and then drawn conclusions (Sugiyono, 2016). The population in this study were all nurses implementing at UPTD. Bali Mandara Regional Hospital in 2018, amounting to 230 people.

According to Sugiyono (2016) the sample is part of the number and characteristics possessed by the population. The sample is a subset of the population, consisting of several members of the population. This subset was taken because in many cases it is not possible to examine all members of the population, so we form a population representative called a sample (Ferdinand, 2014). If the population is large, researchers may not examine everything in the population, for example due to limited funds, manpower, and time so researchers can use samples taken from that population. The sample in this study was 115 people.

Therefore, it can be said that a sample is a subset of the population. The sample consists of several members selected from the population. In other words, some, but not all, elements of the population will form the sample. The sample chosen in this study was a sample taken from the population, whose characteristics were examined. According to Ferdinand (2014), the minimum sample size was taken using the indicator number of indicators multiplied by 5 (five) so that the number of samples used in this study was $23 \times 5=$ 115 people. In this study the sampling technique used was Nonpability Sampling that is Proportional Sampling.

Testing Instrument Research uses validity and reliability tests. The data analysis technique used in this study is CB-SEM (Covariance Based-Structural Equation Modeling) with the AMOS (Analysis of Moment Structure) program. According to (Ferdinand: 2014), SEM is a combination of two separate statistical methods, namely to confirm indicators of a latent and structural variable that describes the causal relationship between two or more variables.

\section{DISCUSSION OF RESULTS}

Based on the test criteria, Chi-square, relative Chi-square, RMESEA, GFI, AGFI, TLI and $\mathrm{CFI}$ above and the Goodness of Fit value of AMOS processing as shown in the picture above, then the following table can be made.

Table 1 - Goodness of Fit Analysis

\begin{tabular}{|l|l|l|l|}
\hline Goodness of Fit Indeks & Cut-off Value & Analysis Results & Model Evaluation \\
\hline Chi-Square $\left(\chi^{2}\right)$ & Smaller are better & 268,296 & Not good \\
\hline Relatitive Chi-square $\left(\chi^{2} / \mathrm{df}\right)$ & $\leq 3,00$ & $2,826^{\prime}$ & Good \\
\hline Probability & $\geq 0,05$ & 0,000 & Not good \\
\hline RMSEA & $\leq 0,08$ & 0,059 & Good \\
\hline GFI & $\geq 0,90$ & 0,858 & Marginal \\
\hline AGFI & $\geq 0,90$ & 0,817 & Marginal \\
\hline TLI & $\geq 0,95$ & 0,954 & Good \\
\hline CFI & $\geq 0,95$ & 0,961 & Good \\
\hline
\end{tabular}


Considering the cut-of-value and goodness of fit results of the model in table 4.18 above, of the eight criteria used 4 have met the requirements of goodness of fit namely Relative Chis Square, RMSEA, TLI and CFI, 2 (two) marginal criteria namely GFI and AGFI and only two criteria are not good. Menurt Solimun (2010:61) states that: "If there are one or two Goodness of Fit criteria that have met, the model is said to be good". But if the model is not good then modification is needed.

Model testing is done using regression coefficients (regression weights) for leadership variables (X1), organizational culture (X2), work environment (X3), job satisfaction (Y1) and caring behavior (Y2).

Table 2 - Analysis of Structural Equation Models

\begin{tabular}{|c|c|c|c|c|c|c|c|c|}
\hline \multicolumn{2}{|c|}{$\mathrm{n} / \mathrm{n}$} & $\begin{array}{c}\text { Unstandarized } \\
\text { Estimate }\end{array}$ & $\begin{array}{c}\text { Standarized } \\
\text { Estimate }\end{array}$ & S.E. & C.R. & P & Information \\
\hline Y1 & $<---$ & $\mathrm{X} 1$ & .260 & .290 & .068 & 3.803 & ${ }^{\star * \star}$ & Significant \\
\hline Y1 & $<---$ & $\mathrm{X} 2$ & .246 & .300 & .069 & 3.546 & ${ }^{\star * \star}$ & Significant \\
\hline Y1 & $<---$ & $\mathrm{X} 3$ & .618 & .460 & .147 & 4.200 & ${ }^{\star * \star}$ & Significant \\
\hline Y2 & $<---$ & $\mathrm{X} 3$ & .126 & .162 & .070 & 1.803 & .071 & Not Significant \\
\hline Y2 & $<---$ & $\mathrm{X} 1$ & .074 & .143 & .035 & 2.093 & .036 & Significant \\
\hline Y2 & $<---$ & Y1 & .291 & .503 & .083 & 3.491 & ${ }^{* *}$ & Significant \\
\hline Y2 & $<---$ & X2 & .100 & .211 & .037 & 2.680 & .007 & Significant \\
\hline
\end{tabular}

Table 3 - Analysis of Measurement Models by Determination

\begin{tabular}{|c|c|}
\hline $\mathrm{n} / \mathrm{n}$ & Estimate \\
\hline Job satisfaction (Y1) & .752 \\
\hline Caring behavior (Y2) & .800 \\
\hline
\end{tabular}

Based on the data in table 4.21 above, it appears that the value of Squared Multiple Correlations for the job satisfaction variable is 0.752 and for the caring behavior variable is 0.800. According to Ferdinand (2014: 114) the value of Squared Multiple Correlations is identical to R2 in SPSS. The value of determination (D) is Squared Multiple Correlations $x$ $100 \%$. So the magnitude of the coefficient of determination (D) the variable of job satisfaction is $0.752 \times 100 \%=75.2 \%$. Thus it can be stated that changes in job satisfaction are influenced by leadership, organizational culture and work environment by $75.2 \%$. While the rest of $100 \%-75.2 \%=24.8 \%$ is influenced by factors outside this research model.

\section{CONCLUSSION AND SUGGESTIONS}

Based on the results of the discussion above, it can be concluded as follows that there is a significant positive influence between leadership on job satisfaction. This means that the better the leadership the more job satisfaction will increase. Vice versa if the worse the leadership will decrease job satisfaction. There is a significant positive influence between organizational culture on job satisfaction. This means that the better the organizational culture, the more job satisfaction will increase. Vice versa if the worse the organizational culture, the job satisfaction will decrease. There is a significant positive effect between work environment on job satisfaction. This means that the better the work environment, the more job satisfaction will increase. Vice versa if the worse the work environment will decrease job satisfaction. There is a significant positive influence between leadership on caring behavior. This means that the better the leadership, the more caring behavior will increase. Vice versa if the worse the leadership will decrease caring behavior. There is a significant positive influence between organizational culture on caring behavior. This means that the better the organizational culture, the more caring behavior will increase. Vice versa, if the worse the organizational culture, the caring behavior will decrease. There is no significant positive effect between work environment on caring behavior. This shows that the work environment has an influence on caring behavior, but the effect is very weak. There is a significant positive effect between job satisfaction on caring behavior. This means that the better job 
satisfaction, the more caring behavior will increase. Vice versa if the worse the job satisfaction will decrease caring behavior.

Suggestions that can be given for this research are the results of the analysis show that the most dominant variable which affects job satisfaction is the working environment at UPTD RSUD Bali Mandara, so that it can be suggested that nurse job satisfaction can be improved by managing the working environment. If the employee feels comfortable and safe with the work environment where they works, then the nurse will feel satisfied and show good efforts and of course, satisfy patients who seek treatment at UPTD Hospital Bali Mandara. Work environment variables have no significant positive effect on caring behavior, this means that the work environment has an unreal impact or influence on caring behavior. The most dominant factor influencing nurses caring behavior is job satisfaction from nurses. For this reason, it is suggested to UPTD Hospital Bali Mandara should prioritize nurses' job satisfaction development programs. For further research it is recommended that in his research using other variables outside the independent variables used in this study. Or combining the variables in this study in other variables outside of this research variable besides being carried out on different objects such as different locations because these differences allow different research results. Taking research objects for different professions and different business fields can produce different findings.

\section{REFERENCES}

1. Aditya. (2016). Pengaruh Tingkat Kepuasan Perawat Terhadap Perilaku Caring Di Ruang Rawat Inap Rsud Kartini Jepara. Jurnal Keperawatan Stikes Telogorejo Semarang.

2. Afrizal, R. (2012). Analisis Pengaruh Gaya Kepemimpinan, Lingkungan Kerja and Kompensasi Terhadap Kepuasan Kerja Karyawan PT. Nindya Karya Persero.(http://publication.gunadarma.ac.id/bitstream/123456789/6263/1/ jurnal.pdf).

3. Agustin, I. (2002). Perilaku Caring Perawat and Hubungannya dengan Kepuasan Klien di Instalasi Rawat Inap Bedah Dewasa di Rumah Sakit Dr. Mohammad Hoesin Palembang. http://www.digilib.ui.ac.id/opac/themes/libri2/metadatapdf.jsp?id=70660. Diunduh 12 Desember 2018.

4. Agustina. (2013). Pengaruh Kepemimpinan Transformasional and Budaya Organisasi Terhadap Kepuasan Kerja and Kinerja Karyawan Pt. Jamsostek (Persero) Cabang Surabaya. DIE, Jurnal IImu Ekonomi \& Manajemen. Januari 2013, Vol. 9 No.1, hal. 8293.

5. Anak Agung Ngurah Bagus Dhermawan \& Riansari, (2012), Pengaruh Motivasi, Lingkungan Kerja, Kompetensi and Kompensasi Terhadap Kepuasan Kerja and Kinerja Pegawai di Lingkungan Kantor Dinas Pekerjaan Umum Provinsi Bali, Jurnal Manajemen, Strategi Bisnis and Kewirausahaan, Vol. 6.

6. Anjani. (2016). Pengaruh Budaya Organisasi Terhadap Kepuasan Kerja Karyawan Telkom Foundation (Tf). Tesis Manajemen Bisnis Telekomunikasi and Informatika, Fakultas Ekonomi and Bisnis, Universitas Telkom.

7. Bateman, Thomas S. \& Scott A. Snell. (2008). Manajemen Kepemimpinan and Kolaborasi dalam Dunia yang Kompetitif 1: Edisi 7. Jakarta. Penerbit Salemba Empat.

8. Bernardine \& Wirjana. (2006). Kepemimpinan Dasar-dasar and Pengembangannya. Edisi Kedua. Yogyakarta. Andi.

9. Bijaya, A. (2006). Pengaruh budaya organisasi terhadap kinerja perawat di ruang rawat inap rumah sakit Dr. H. Marzoeki Mahdi Bogor. Tesis Program Magister Ilmu Keperawatan FIK UI.

10. Byrne \& Heyman. (2015). Existential advocacy: Phylosophical foundation of nursing (nursing image and ideas). New York: Springer Publishing Co.

11. Cepi Priatna. (2015), Perilaku Organisasi. PT. Remaja Rosdakarya. Bandung.

12. Dwi Agung Nugroho Arianto. (2013). Pengaruh Kedisiplinan, Lingkungan Kerja and Budaya Kerja Terhadap Kinerja Tenaga Pengajar (Studi Pada Yayasan Pendidikan Luar Biasa Kabupaten Demak). Jurnal Economia, Vol 9 N0 2 Hal 191-200.

13. Dwidiyanti, Meidiana. (2010). "Konsep Caring". Semarang: Hasani. 
14. Ferdinand, Augusty. (2014). Metode Penelitian Manajemen. Semarang. BP Universitas Diponegoro.

15. Ghozali, Imam. \& Hengky, Latan. (2012). Partial Least Square: Konsep, Teknik and Aplikasi Menggunakan Program Smart PLS 2.0 M3.. Semarang: Universitas Diponegoro.

16. Handoko. (2016). Manajemen Sumber Daya Manusia (edisi revisi). Yogyakarta: BPFE.

17. Huber, D. (2006). Leadership and nursing care management. Philadelphia: WB Saunders Company.

18. Ikafah. (2017). Perilaku Caring Perawat Dengan Kepuasan Pasien Di Ruang Rawat Inapprivate Care Centre Rsup Dr Wahidin Sudirohusodo Makassar. Versi Online: Volume 8, Nomor 2, Juli 2017 Http://Ejournal.Umm.Ac.Id/Index.Php/Keperawatan/Issue/View.

19. Kathyrine A. (2018). Caring Behavior and Patient Satisfaction: Merging for Satisfaction. International Journal of Caring Sciences May-August 2018 Volume 11. Issue 2. Page 697

20. Khajeh, E. (2018). Impact of Leadership Styles on Organizational Performance. Journal of Human Resources Management Research http://ibimapublishing.com/articles/JHRMR/2018/687849/ Vol. 2018 (2018), Article ID 687849, 10 pages, ISSN: 2166-0018 DOI: 10.5171/2018.687849.

21. Kholipah, S., Susilo, E., \& Purwaningsih, H. (2013). Hubungan Penerapan Budaya Organisasi Dengan Kepuasan Pasien Di RSUD Ambarawa. Jurnal Managemen Keperawatan Volume 1, No. 1, 7-14.

22. Kimble, L. (2010). Thesis Patients perceptioms of nursing caring behavior in an emergency department. Marshall University College of Nursing and Health Professions.

23. Kuswantoro, R.P. (2006). Hubungan Lingkungan Kerja Perawat Dengan Pelaksanaan Praktek Keperawatan di Rumah Sakit Umum Dr. Syaiful Anwar Malang. Tesis Program Pasca Sarjana. FIK UI.

24. Kreitner, R \& Kinicki. (2010). Organizational Behaviour. New York: Mc Graw-Hill Higher Education.

25. Lazuardy, Taufiq, Yuwaldi Away and M. Shabri Abd. Majid. (2014). Pengaruh Kepemimpinan and Budaya Organisasi terhadap Kepuasan Kerja serta Dampaknya pada Kinerja Pegawai Negeri Sipil Setdakab Aceh Barat Daya. Jurnal Manajemen Pascasarjana Universitas Syiah Kuala Volume 3, No. 2. h. 94- 101.

26. Mamesah, M.M. and Amiartuti, K. (2009).Pengaruh Gaya Kepemimpinan Transformasional danTransaksional terhadap Kepuasan kerja and Dampaknya terhadap Kinerja Karyawan.Jurnal Akuntansi, Manajemen Bisnis, and Sektor Publik. Vol. 5. No. 3. ISSN: $1829-9857$.

27. Malini, H (2009). Hubungan Kecerdasan Spiritual Dengan Perilaku Caring Perawat di RSMD Jamil Padang.

28. Manulang. (2015). Dasar-dasar manajemen. Yogyakarta: Ghalia.

29. Menkes RI (Dirjen Yanmed). (2014). Pedoman Pelaksanaan jaminan kesehatan masyarakat (Jamkesmas) tahun 2005. Jakarta: Departemen Kesehatan RI.

30. Morrison, P. \& Burnard, P. (2009). Caring and Communicatting: hubungan interpersonal dalam keperawatan. Edisi kedua. (Terj. Widyawati, E. Meiliya). Jakarta: EGC.

31. Muhlisin. A. \& Ichsan, B. (2008). Aplikasi model konseptual caring dari Jean Watson dalam Asuhan Keperawatan. Berita IImu Keperawatan ISSN1979-2697. Vol.1 No. 3, Desember 2018:147-150.

32. Nasution, Erni H. (2018). Faktor-Faktor yang Mempengaruhi Kepuasan Kerja and Dampaknya Terhadap Kinerja Pegawai Kanwil Direktorat Jenderal Kekayaan Negara Aceh. Jurnal Magister Manajemen Fakultas Ekonomi and Bisnis Unsyiah. ISSN 23020199. pp. 123-134.

33. Nikpour, Amin (2017). The impact of organizational culture on organizational performance: The mediating role of employee's organizational commitment. International Journal of Organizational Leadership 6(2017) 65-72.

34. Nurachmah, E. (2010). Persepsi klien tentang asuhan keperawatan bermutu and tingkat kepuasan.

35. Nursalam. (2009). Manajemen Keperawatan: Aplikasi dalam Praktik Keperawatan Profesional. Jakarta: Salemba Medika. 
36. Paramita, Widya. (2013). "Pengaruh Lingkungan Kerja and Budaya Organisasi Terhadap Kepuasan Kerja Karyawan pada Bank BTN (Persero Cabang Bekasi)". Jurnal Riset Manajemen Sains Indonesia. Vol. 4, No. 2, p.257-275.

37. Prihandini. (2015). Hubungan Faktor Individu and Budaya Organisasi Dengan Perilaku Caring Perawat Pelaksana Di Ruang Rawat Inap Rumah Sakit Umum Ganesha Gianyar.

38. Robbins, S. \& Judge, Y. (2010). Perilaku organisasi. (Terj. D. Angelica, R. Cahyani, and A. Rosyid) Edisi 12. Jakarta: Salemba Empat (Buku asli tahun 2007).

39. Sagita, AA. (2018). Pengaruh Budaya Organisasi Terhadap Kinerja Karyawan Dengan Motivasi Kerja Sebagai Variabel Mediator (Studi Pada PT Astra Internasional, TbkToyota (Auto2000) Cabang Sutoyo Malang). Jurnal Administrasi Bisnis (JAB). Vol. 57 No.1 April 2018.

40. Sedarmayanti. (2014). Sumber Daya Manusia and Produktifitas Kerja. Jakarta: Mandar Maju.

41. Selvia, N. (2013). Perbedaan stress kerja ditinjau dari shift kerja pada perawat di RSUD Dr. Soetomo Surabaya. Jurnal psikologi, vol. 2 No, 01 Februari 2013. Fakultas psikologi universitas Airlangga.Surabaya.

42. Shahab, M.A., Nisa, I. (2014). The Influence of Leadership and Work Attitudes toward Job Satisfaction and Performance of Employee. Internasional Journal of Managerial Studies and Research, Volume 2, 69-77.

43. Sondang P. Siagian. (2009). Kiat Meningkatkan Produktivitas Kerja. Jakarta: PT Rineka Cipta.

44. Steven. (2016). Pengaruh Budaya Organisasi Terhadap Kepuasan Kerja, Komitmen Organisasional and Intention To Leave Jurnal Bisnis and Manajemen Vol. 3 No.1.

45. Sugiyono. (2016), Metode Penelitian Bisnis. Bandung: Alfabeta.

46. Supriatin, E. (2009). Hubungan beban kerja and pengembangan profesional and perilaku caring perawat pelaksana di RS Cikini Jakarta. Tesis Program Magister IImu Keperawatan FIK UI.

47. Suryani. (2010). Hubungan beban kerja and pengembangan profesional and perilaku caring perawat pelaksana di RS Cikini Jakarta. Tesis Program Magister IImu Keperawatan FIK UI. Tidak dipublikasikan.

48. Suarli, S \& Bahtiar. (2009). Manajemen keperawatan dengan pendekatan praktis. Jakarta: Erlangga.

49. Tomey, AM, \& Alligood, MR. (2006). Nursing theorists and their work. Six edition. Missouri: Mosby Elsevier.

50. Wahyuningsih, Putri. (2012). "Pengaruh Letak Kendali Diri, Jabatan Organisasi, Konflik Peran and Budaya Organisasi Terhadap Kepuasan Kerja". Jurnal, STIE Perbanas Surabaya, Surabaya.

51. Watson, J., Sitzman, K. (2005). Caring science as secret science. Philadelphia: Davis Company.

52. Watson, J., Sitzman, K. (2014). Caring Science, Mindful Practice: Implementing Watson's Human Caring Theory. New York: Springer Publishing Company.

53. Wibowo. (2010). Manajemen kinerja. Jakarta: Raja Grafindo Persada.

54. Wirawan. (2007). Budaya and IklimOrganisasi. Jakarta: Salemba Empat.

55. Wolf, Z.B., Colahan, M., Costello, A.,Warwick, F., Ambrose, M.S., \& Giardino E.R. (2004). Relationship between nurse caring and patient satisfaction. JurNal Medsur Nursing, 7(2). 99-105. September 29, 2018. http://findarticles.com/p/articles/mi. 